\title{
ACHIEVING SUSTAINABLE DEVELOPMENT THROUGH TAX HARMONIZATION: POTENTIALS, PARADOXES AND POLICY IMPERATIVES
}

\author{
Aniyie Ifeanyichukwu Azuka*
}

U sing Nigeria as a case study, this article examines the efficacy of tax harmonization as an option for the achievement of two objectives: the integration of a developing country with other economies, and its sustainable development. It highlights the nexus between tax harmonization - a tax policy option - and sustainable development, as well as the potentials and paradoxes of tax harmonization. The article proceeds on the premise that striking the right balance between the multiplicity of policy options when designing and implementing tax policies is a great challenge for governments; tax harmonization can be adopted for diverse reasons; and the policy of harmonization within the tax sphere impacts on development of the state. The article discusses how practical barriers and challenges associated with implementing tax harmonization may be navigated through empirical information and/or research.

Keywords: Tax, harmonization, sustainable development, Nigeria, economy.

doi: http://dx.doi.org/10.4314/jsdlp.v6i1.12

* MPhil Taxation (Pretoria); LLM (Benin); BL., ACIArb. (UK); ACTI. Associate Research Fellow, Institute for Oil, Gas, Energy, Environment and Sustainable Development, Afe Babalola University, Nigeria. 


\section{INTRODUCTION}

Jotwithstanding the fact that power to tax is coterminous with the affect economic life in other states, and may influence the economic indices and the development trajectory of taxing state in diverse ways. For example, a tax policy that is oriented towards incentives and exemptions is a base for revenue loss ${ }^{2}$ and from the development perspective the lost revenue is lost development opportunity. ${ }^{3}$ The existence of high corporate tax rate in a country or state relative to others is a disincentive to foreign capital movement; and may cause outflow of capital or its shift to jurisdictions with less burdensome tax regime. The aforementioned is also part of the rationale behind the competition to attract investment. Tax harmonization is touted as an option for ameliorating the consequences of the seeming extra-jurisdictional tax reach of a sovereign ${ }^{4}$ as well as issues like the welfare or deadweight loss associated with the decision of economic actors within jurisdiction. ${ }^{5}$

1 Joseph Beale, “Jurisdiction to Tax" (1919) Vol. 32 (6), Harvard Law Review, 587.

2 Total revenue losses suffered by the 15 members of the Economic Community of West African States (ECOWAS) as result of tax incentives has been put at US\$9.6 million. For Ghana, the average revenue losses from corporate tax incentives for 2011-14 has been put at US\$693 million. See ActionAid, “The West African Giveaway: Use and Abuse of Corporate Tax Incentives in ECOWAS” (July 2015), 4.

3 The International Monetary Fund (IMF) in 2015 put the value of discretional tax treatment in Ghana at three times the allocation for health. Ibid 13. According to ActionAid, the value of the tax incentive in Kenya for 2010/11 of about KShs 100 billion is almost twice the government's entire health budget of KShs 41.5 billion. See ActionAid, “Tax Competition in East Africa: A Race to the Bottom? Tax Incentives and Revenue Losses in Kenya” (May 2012), 9 <www.taxjustice.net/ cms/upload/pdf/kenya_report_full.pdf $>$ accessed 10 October 2015.

4 Fernando Velayos, et al. "Regional Integration and Tax Harmonisation: Issues and Recent Experiences” <http://siteresources.worldbank.org/INTTPA/ Resources/Velayos-Villela-Barreix.pdf> accessed 21 September 2013. See also, Kenneth Bagamuhunda, 'Status and Road map of Tax Harmonisation in EAC' <www.wbginvestmentclimate.org/advisory-services/regulatory-simplification/ business-taxation/upload/Status-and-Road-map-of-Tax-Harmonization-inEAC-Kenneth-Bagamuhunda.pdf> accessed 1 September 2013

5 Welfare or deadweight loss refers to the economic or efficiency cost imposed by taxes or associated with taxation and is distinct from administrative and compliance cost. It is a function of the decision altering (or inducing) impact of taxes on economic actors. See James R. Hines, “Excess Burden of Taxation” (2007) Michigan Ross School of Business WP 2007-1 <www.bus.umich.edu/otpr/ WP2007-1.pdf> accessed 1 July 2015. 
Tax harmonization has assumed global prominence. The driver for this is globalization, the emergence of open borders, factor mobility and the pressure to compete with neighbours for investment, the re-insurgence of economic and trade groupings, etc. What is tax harmonization? Tax harmonization refers to the process, whether conscious or otherwise, of making taxes identical or similar across regions. It is a tool used in dealing with the corollaries associated with interaction of the different tax systems of the world. ${ }^{6}$ The product of tax harmonization is the existence of harmonized tax rates or administrative process amongst states, regions or groupings. It is an orientation that has been adopted in different corners of the globe ${ }^{7}$ and is of varied levels or degrees (to wit: standardization, compatibility, coordination, cooperation and convergence). ${ }^{8}$

What does tax harmonization portend for developing countries or how does it impact on their development? The answer to this question is distillable from an understanding of the relationship between taxation, development and institutions in the state. The trio influence, shape, and colour one another. The socio-economic institutions of a state are major determinants of its capacity to attract investments and development potential. ${ }^{9}$ On its part, taxation can impact on economic and political

6 Andrew Lymer and John Hasseldine (eds.), The International Taxation System (Springer Science + Business Media, 2002) 117.

7 It is the basis for the adoption of the Consolidated Version of the Treaty on European Union (TEU) and the Treaty on the Functioning of the European Union (TFEU) [2012] C 326, p. 0001-0390; the Council Directive (EC) 2006/112 of 28 November 2006 on the common system of value added tax. See generally, Official Journal of the European Union Notice/C 115/01 <http://eurlex.europa.eu/legal-content/EN/TXT/?uri=OJ:C:2008:115:TOC > accessed 3 July 2015. On the African continent, it is premise for article 32-34, Protocol on the Establishment of the East African Community Common Market sequel to which tax policies, law and administration is being pursued amongst members of the East African Community. See generally, <www.eac.int/commonmarket/ index.php?option $=$ com_docman\&task $=$ cat_view\&gid $=30 \&$ Itemid $=6>$ accessed 3 July 2015. Tax harmonisation is considered a corollary of the signing of the Southern African Development Community Protocol on Trade (1996) because, sequel to it, member of the Southern African Development Community (SADC) are obligated to amend their tax laws with a view to eliminating all barriers to trade in or with them by other SADC members. See <www.sadc.int/files/4613/ 5292/8370/ Protocol_on_Trade1996.pdf> accessed 3 July 2015.

8 See Velayos (n 5) $5 \mathrm{ff}$. 
instability (or change) ${ }^{10}$ as well as development. ${ }^{11}$ Another manifestation of the relationship is that taxation is the exercise of sovereign power by the state. It provides a basis for consensual interaction and public participation in the political structuring and governance of the state. ${ }^{12} \mathrm{It}$ also allows for a bottom-up approach to dealing with the developmental issues of the State. Furthermore, taxation, as a means of state or public financing, is in line with the principle of sustainable development (also referred to as sustainability principle) as it ensures that the machinery for sourcing of public finance is established and operates in a manner that at least maintains (and sometimes enhances) the physical, social and economic environment for the benefit of current and future generations. ${ }^{13}$

9 See Ifeanyichukwu A. Aniyie, "Foreign Investment and the Development of the Third World: An Examination of the Realities" (2012) Vol. 1, Journal of Contemporary Law 155,159-165 where socio-economic factors (institutions inclusive ) that influence inflow of investment into the third world were examined.

10 For example, in Ghana, widespread public protest led to the repeal of a 17 per cent value added tax in 1995; its redesign eventual repeal of the legislation. See Ghana Mining Laws and Regulations Handbook (Vol 1) (USA, 2015) 33.

11 The National Health Insurance Levy and the Communication Service Tax of Ghana are examples of the use of tax proceeds for specific developmental purpose. The former is used to fund health insurance schemes for Ghanaians; while the latter is earmarked for the finance of the Ghanaian National Youth Employment Programme. See generally, Nathan J Blanchet, et al, “The Effect of Ghana's National Health Insurance Scheme on Health Care Utilisation” (June 2012) Vol. 46 (2) Ghana Medical Journal 76-84 <www.ncbi.nlm.nih.gov/pmc/articles/ PMC3426378/\#R8> accessed 1 August 2014. See also Ghana Revenue Authority, Tax Information: Value Added Tax <www.gra.gov.gh/index.php?option=com content $\&$ view=article\&id=44\&Itemid=47> accessed 1 August 2014. See also, Ifeanyichukwu A. Aniyie and Ohio Omiunu, 'Optimising the Development Options in the Third World Countries: Looking Beyond Foreign Aid' (2014) 1 (2) Ife Journal of International and Comparative Law 240-259 where taxation was recommended as complementary to foreign aid for moving third world countries into the "take-off stage" of economic development and growth. Also see Oyinlola Olaniyi, "Mismatch between Tax Yield and Revenue Requirement for Financing Social Overhead Capital in Nigeria: Imperatives for an Alternative Revenue Framework" in Josephine Agbonika (ed), Topical Issues on Nigerian Tax Laws and Related Areas (Ababa Press Ltd 2015) 398, 405-406 where the author drew a nexus between tax revenue yield, tax to GDP ratio and capacity to fund socio-infrastructure development in Nigeria.

12 Internationally, public participation has been accepted as a criterion for sustainable development. This is a product of the thinking introduced by Agenda 21. See paragraph 23.2, United Nations Conference on Environment and Development, Agenda 21 UN Doc. A/CONF. 151/26/Rev1, 31 ILM 874 (1992). 
This article examines the option of tax harmonization as a means of achieving economic integration of a developing country with other economies, with focus on Nigeria. It highlights developments in the Nigerian tax system that relate to tax harmonization, the benefits and costs for Nigeria's participation in tax harmonization. The article is qualitative and expository in approach. It reports findings of direct interviews with legal and tax policy personnel; $;^{14}$ reviews key literature on the subject and provides a description of issues that can be termed the "pros and cons" of the policy of tax harmonization and that are capable of crystallizing in Nigeria upon adoption of this tax policy.

Structurally, the paper is divided into six parts. This introduction is the first. Section 2 reviews Nigeria's standing with regard to tax harmonization. Sections 3 and 4, respectively, analyse the benefits and costs associated with the adoption of tax harmonization. Section 5 highlights some challenges capable of impacting on the implementation of a tax harmonization policy by Nigeria. The article concludes in section 6.

\section{TAX HARMONIZATION: WHERE IS NIGERIA?}

Using the Velayos, et al ${ }^{15}$ pyramid of degrees of tax harmonization as a reference point, the table below summarizes the degree of tax harmonization, the instruments of harmonization; i.e., the means adopted in Nigeria for harmonization and the taxes affected by the harmonization.

13 See United Nations World Commission on Environment and Development, Our Common Future (OUP, 1987), ch. 2 <www.un-documents.net/ocf-02.htm\#I> accessed 8 October 2015 .

14 Between August 2013 and March 2014, the author interviewed personnel of the tax policy; legislation department and the legal department of FIRS on the condition of anonymity.

15 Velayos (n 5) 8. 


\begin{tabular}{|c|c|c|}
\hline $\begin{array}{l}\text { Degree of } \\
\text { harmonization }\end{array}$ & $\begin{array}{l}\text { Instrument of } \\
\text { harmonization }\end{array}$ & Taxes affected \\
\hline Standardization $^{16}$ & $\begin{array}{l}\text { ECOWAS CET } \\
\text { ECOWAS VAT Protocol }^{18}\end{array}$ & $\begin{array}{l}\text { Import duties/ tariffs } \\
\text { Value Added Tax (VAT) }\end{array}$ \\
\hline Compatibility $^{19}$ & $\begin{array}{l}\text { Double Tax Agreements } \\
\text { (DTAs) }^{20}\end{array}$ & $\begin{array}{l}\text { Income taxes, }{ }^{21} \text { to wit: } \\
\text { Personal Income } \mathrm{Tax}^{22} \\
\text { Companies Income } \mathrm{Tax}^{23} \\
\text { Petroleum Profits Tax } \\
\text { National Information } \\
\text { Technology Development }\end{array}$ \\
\hline
\end{tabular}

16 This is at the top of the pyramid and is the highest degree of harmonization. It is characterized by the existence of similar taxes on similar tax handles or burdens in different states. An example of standardization is the adoption of a common external tariff (CET) by different states or within a region.

17 The legal mandate for the ECOWAS CET is article 3, ECOWAS Revised Treaty and the ECOWAS Regulation C/REG.1/5/09. The cardinal goal of the CET is the removal of all trade barriers within the ECOWAS region, establishment of a common market and customs union for members as well as free movement of goods and persons within the region.

18 Nigeria is a signatory but is yet to comply with its primary recommendation as VAT is currently charged at 5 per cent in line with the provisions of section 4 , Value Added Tax Act, Cap V1 Laws of the Federation of Nigeria 2004 (as amended) (hereafter referred to as VAT Act)

19 This involves the adjustment of the tax structure or rate of states in the course or process of economic integration. At this level, the focus is to counteract or compensate for the distortions caused by the tax burden disparities between the states in the grouping.

20 DTAs can be bilateral or multilateral. For literature on the types of DTAs, the advantages and disadvantages of the adoption of the types, see Victor Thuronyi, Comparative Tax Law (Kluwer Law International 2003) 121; Kim Brooks, "The Potential of Multilateral Tax Treaties" in Michael Lang, et al. (eds), Tax Treaties: Building Bridges between Law and Economics (IBFD 2010) 211-236. For information on Nigeria's DTA standing, see Appendix 1, infra.

21 These are taxes on income of persons (corporate or individual) from employment, business or property accruing in, derived from, brought into, or received in Nigeria. Nigeria has a model DTA that is used as template for negotiation with prospective treaty partners and it specifically recognises the taxes grouped in this essay as income taxes except the National Information Technology Development Levy.

22 This is charged pursuant to section 3, Personal Income Tax Act, Cap P8 Laws of the Federation of Nigeria 2004 (as amended) (PITA).

23 This is charged pursuant to sections 9 and 13, Companies Income Tax Act, Cap C21 Laws of the Federation of Nigeria 2004 (CITA).

24 The tax is levied pursuant to section 8, Petroleum Profits Tax Act, Cap P13 Laws of the Federation of Nigeria 2004 (PPTA). 


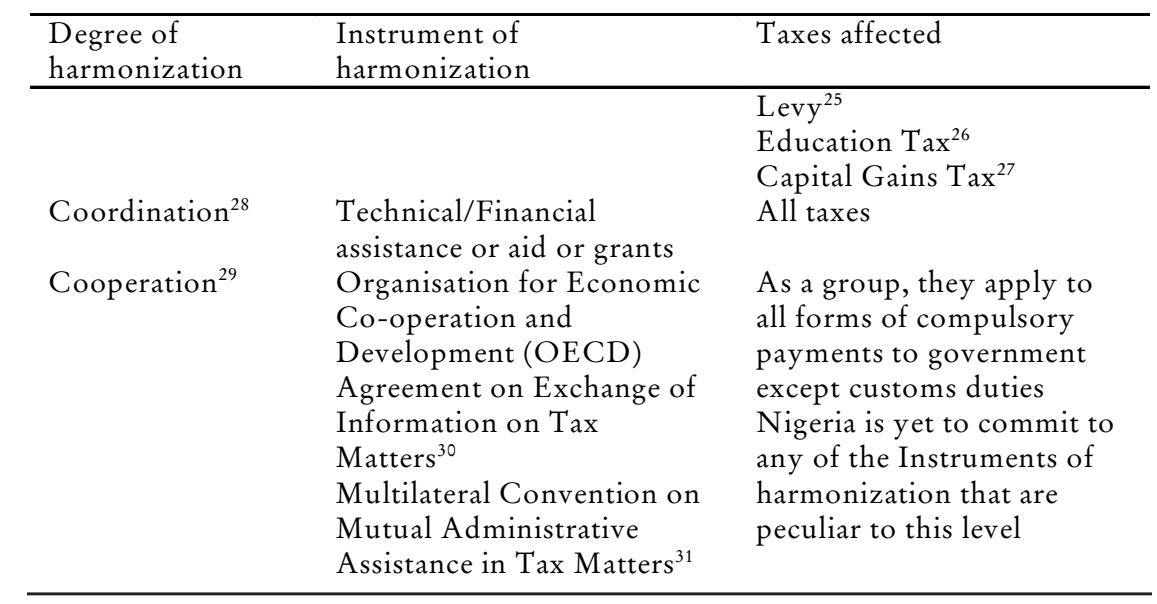

25 The basis of the levy is section 12, National Information Technology Development Agency Act Cap N156, Laws of the Federation of Nigeria 2004 (as amended in 2007) (NITDAA). Though the Nigeria model DTA does not specifically mention the levy, by virtue of its article 2 (3) (VI), the NITDAA and the levy is deemed subject to a DTA fashioned after the Nigeria model DTA.

26 This is levied pursuant to the Tertiary Education Trust Fund Tax Act 2011 (TETFUND Act).

27 This is charged on the gain from the disposal of a qualified capital asset pursuant to the Capital Gains Tax Act, Cap. C1 Laws of the Federation of Nigeria 2004 (CGTA).

28 This is an in-between category and is constituted of all and any endeavour that does not fit into the other four categories. Technical assistance/aid, training etc. pertaining to taxation provided by multilateral or donor agencies to states can be categorized as coordination. For the purpose of this paper, procedural arrangements aimed at information exchange are grouped as cooperation. This is not without acknowledgment of the fact that some scholars have included them in this group. See Thomas Hemmelgarn and Gaetan Nicodeme, "Tax Coordination in Europe: Assessing the First years of the EU-Savings Taxation Directive”, (2009) CESIFO Working Paper No. 2675 <www.cesifo-group.de/ portal/page/portal/9684335711730D9FE04400144FAFBA7C > accessed 21 June 2014.

29 This is characterized by mutual assistance actuated by either reciprocity or mutual interest. Procedural arrangements aimed at exchange of information are grouped as cooperation.

30 See <www.oecd.org/ctp/exchange-of-tax-information/2082215.pdf $>$ accessed 19 August 2013.

31 Hereafter referred to as Multilateral Convention. It allows, among other things, automatic exchange of information, simultaneous tax examinations and assistance in the collection of tax debts. This was initially developed for application within the jurisdiction of OECD and the Council of Europe members. Subscription was later opened to all countries vide a Protocol which came into force on 1 June 2011. Nigeria, on 29 March 2013 signed the OECD Multilateral Convention. See “Nigeria Signs OECD's Multilateral Convention on Mutual Administrative Assistance in Tax Matters" (2013) Gauge (A Quarterly Publication of the Federal Inland Revenue Service) 27. 


\begin{tabular}{lll}
\hline $\begin{array}{l}\text { Degree of } \\
\text { harmonization }\end{array}$ & $\begin{array}{l}\text { Instrument of } \\
\text { harmonization }\end{array}$ & Taxes affected \\
\hline & Tax Information Exchange & \\
& Agreements (TIEAs) & \\
& ATAF Agreement on & \\
& Mutual Assistance in Tax & \\
Matters & All taxes \\
Convergence & & \\
& Income Tax (Transfer & \\
& Pricing) Regulations 2012 & \\
& (ITR) & \\
& Tax Administration (Self & \\
& Assessment) Regulations & \\
& 2011 (TASAR) & \\
& Federal Inland Revenue & \\
& Service (Establishment) Act \\
& 2007 (FIRSEA) \\
& Adoption of International \\
& Reporting Standards (IFRS) \\
\hline
\end{tabular}

\section{BENEFITS OF TAX HARMONIZATION}

Tax harmonization is a desirable policy for promoting sustainable development in emerging economies. For Nigeria, many benefits can be identified, including the ones discussed below.

\subsection{Uniformity and Certainty}

Within regional/supranational entities or amongst states, tax

32 The purpose of TIEAs is to promote international cooperation in tax matters through exchange of information. They grew out of the work undertaken by the OECD to address harmful tax practices.

33 This is a movement by states (sometimes unwanted) towards harmonization. Convergence could be catalysed by globalization and/or competition. It is characterized by the existence of discomfort, passivity or the orientation that a state must go with the trend or that it cannot escape the trend.

34 The ITR gives effect to the provisions of section 17, PITA; section 22, CITA; section 15, PPTA and inter alia has the objective of ensuring that Nigeria is able to tax on an appropriate basis corresponding to the economic activities embarked upon by taxable persons within Nigeria, including their transactions and dealings with associated enterprises; reduce the risk of double taxation. See Regulations 1-3, ITR.

35 The TASAR sets out processes, procedures and provide standard guidelines for the implementation in Nigeria of the self assessment regime of tax administration.

36 The FIRSEA established the Federal Inland Revenue Service (FIRS) and vests it with the responsibility of administering the different taxes specified in its First Schedule on behalf of the Federal Government of Nigeria. 
harmonization is a veritable tool for ensuring that there is uniformity and certainty in the tax systems in the region. For example, within ECOWAS, in the absence of harmonization, a corporate entity resident in Nigeria and operating in other states within the region will be faced with varied treatment and divergence arising from the peculiarity of the various tax systems subsumed within ECOWAS. An example of the foregoing is that relating to classification (and by extension, treatment). A company classed (segmented and stratified) as a medium taxpayer in Nigeria may not be so classed in Sierra Leone where it carries out similar operations. This and the existence of different accounting/tax regime would lead to the absence of uniformity, uncertainty, the existence of varied obligations and burdens on the company.

This plays out with regards to VAT administration in Ghana and Nigeria. It is compulsory for all resident and non-resident companies doing business in Nigeria to register for VAT, ${ }^{37}$ while there is a registration threshold in Ghana. ${ }^{38}$ The consequence of the foregoing is that an entity below the registration threshold in Ghana but providing goods and services in Nigeria, must register for VAT in Nigeria. However, this is not the case where there is some degree of tax harmonization between both jurisdictions. Attendant also in the circumstances is cost saving associated with economies of scale. The uniformity induced by harmonization comes with the added benefit of providing a tool for combating forum shopping. Forum shopping exists when an economic actor domiciles business interests in a jurisdiction region for the duration of the existence of economic benefit(s) for so doing and upon effluxion of the latter, relocates the business interest from the jurisdiction. It also introduces cost certainty, which is desirable for business planning.

\subsection{Reduction in Spatial Externalities}

Whatever the degree of tax harmonization achieved, there is the benefit of a reduction in spatial externalities. An example of this is the reduction of the level of cross-border revenue shift or loss suffered by states. With

37 See sections 1-3 and 8-9 VAT Act.

38 A business making taxable supplies of goods and services in excess of GHC 10,000 over a 12-month period or has annual turnover of GHC 90,000 or less is required to register for VAT purposes. See Deloitte, 'Ghana: Highlights 2012' (2012) <www.deloitte.com/assets/DcomGlobal/Local\%20Assets/Documents/Tax/ Taxation\%20and\%20Investment\%20Guides/2012/dttl_tax_highlight_ 2012_Ghana.pdf> accessed 14 August 2013. 
DTAs, Nigeria is able to reduce the quantum of loss suffered as a result of factor mobility (capital and labour). ${ }^{39}$ This is also the case with the adoption of the CET. It is bound to reduce cross-border arbitrage. If (and when) Nigeria adopts the recommendation of the ECOWAS VAT Protocol, the revenue accruing to neighbouring jurisdictions with higher VAT rates when items purchased in Nigeria are sold will be no more and the cross-border loss of revenue suffered by Nigeria as a result of the sale of consumer goods bought in Nigeria (a low consumption tax jurisdiction) in high tax jurisdictions would be checked.

\subsection{Combat Tax Planning Manoeuvres}

The existence of modern financial instruments, variance in tax systems, accounting and tax rules/practices, provides transnational corporations (TNCs) and resident taxpayers with opportunity for tax planning manoeuvres. This should be an issue of importance to Nigeria, firstly, of its dependence on oil revenue and the fact that TNCs own about 40 per cent of the factors that are put to production in the oil industry. ${ }^{40}$ Secondly, these factors are a contributor to the tax revenue from the oil industry (Nigeria's major source of revenue). ${ }^{41}$ Thirdly, on the average, they are utilized in the production of about two-third of the total revenue collected from the sector. ${ }^{42}$

With reference to international tax avoidance and evasion, a convergence in accounting and tax rules/practices will be of immense benefit to Nigeria. This is because it will aid in the removal of the variance which make tax planning manoeuvres attractive to TNCs. Transfer pricing, double dipping, thin capitalization, treaty shopping, patronage of tax havens and inversion transactions can be combated with DTAs modelled after the United Nations (UN) Model Double Taxation

39 For example see article 20 of the Agreement between the Government of the Federal Republic of Nigeria and the Government of the Peoples' Republic of China for the Avoidance of Double Taxation and the prevention of Fiscal Evasion with Respect to Taxes on Income (Nigeria-China DTA) which provides the template for the taxation of teachers and researchers.

40 See Joint Venture Operations <www.nnpcgroup.com/NNPCBusiness/ UpstreamVentures.aspx $>$ accessed 2 September 2013.

41 Tax revenue from the oil industry was 63.46 per cent of the total tax revenue from 2001-2011. See Appendix 2 infra for a summary of FIRS collection from 2001-2011.

42 This amounted to 62.9 per cent of the total revenue collected from 2008 to 2012. See Appendix 3 infra for a summary of revenue collection from 2008 to 2011. 
Convention between Developed and Developing Countries (UN Model), ${ }^{43}$ subscription to the Multilateral Convention on Administrative Assistance in Tax Matters, TIEAs and the implementation of a system of profit consolidation combined with formulary apportionment as alternatives to the separate accounting (SA) rules which currently govern the taxation of TNCs. ${ }^{44}$

\subsection{Combating Competition}

It stands to reason that in a globalized and economically integrated world, states would compete for tax bases and inadvertently provide TNCs with incentive to engage in manoeuvres that are capable of jeopardizing tax systems. An option often implemented for this purpose is the reduction of tax rates. Juxtaposed against the need for social spending and rectifying economic distortions, the downside of this option is that tax contribution

43 The UN Model is recommended because it gives more recognition to the source country principle of taxation of active income than what is provided for under the OECD Model Tax Convention on Income and Capital (OECD Model). This benefit is of importance and desirable where the orientation is the attraction and retention of foreign investment within the borders of Nigeria. For an analysis of the UN and OECD Models, see Michael Lennard, "The UN Model Tax Convention as compared with the OECD Model Tax Convention - Current Points of Difference and Recent Developments" (Jan/Feb 2009) Asia-Pacific Tax Bulletin, $4<$ www.taxjustice.net/cms/upload/pdf/Lennard_0902_UN_Vs_ OECD.pdf>laccessed 7 July 2013. See also UN, United Nations Model Double Taxation Convention between Developed and Developing Countries (NY: 2011) $<$ www.un.org/esa/ffd/documents/UN_Model_2011_Update.pdf $>$ accessed 7 July 2013. Cf. article 5 of the UN and OECD Models.

44 This is preferred as it provides a means of combating the challenge of searching for and identifying comparable options posed by the utilization of the SA/transfer pricing rules. For arguments in favour of the utilization of formulary apportionment, see Jit Han Dennis Tan, "Unitary Formulary Apportionment as a Solution to the Conundrum of Source" <www.jmls.edu/academics/taxeb/pdf/ Faherty_1.pdf > accessed 17 July 2013; Tax Justice Network, “Transfer Pricing in Developing Countries: An Introduction" <www.taxjustice.net/cms/upload/ pdf/TP_in_developing_countries.pdf $>$ accessed 2 July 2013; Reuven S. AviYonah, et. al, "Allocating Business Profits for Tax Purposes: A Proposal to Adopt a Formulary Profit Split” (2009), Vol. 9 (5) Florida Tax Review $497<$ http:// repository.law.umich.edu/cgi/viewcontent.cgi ?article=1773\&context=articles $>$ accessed 9 October 2015; Reuven S. Avi-Yonah and IIan Benshalom, "Formulary Apportionment: Myths and Prospects - Promoting Better International Tax Policy and Utilizing the Misunderstood and Under-Theorized Formulary Alternative" (2011) 3 (No.3) World Tax Journal 371-398<http://repository.law.umich.edu/ cgi/viewcontent.cgi ?article $=2180 \&$ context=articles $>$ accessed 9 October 2015 . 
to total national revenue will be at inefficiently low levels. The situation is worsened by the fact these states often do not have policies and/or strategies to counter the effect(s) of tax rate reduction on the economy whose range includes a steady drop in government revenue to reduced expenditure outlay for social welfare and services, etc.

Tax harmonization is an option for dealing with the propensity to compete for tax bases among states. The reasoning behind this assertion is premised on a stylized version of the rational taxpayer model, which posits that where taxes are not harmonized, other things being equal, economic actors will migrate to jurisdictions where there is the possibility of paying less tax. In the face of this, states will be drawn into a competition to provide the lowest tax rates. Therefore, with uniformity there is bound to be a reduction in the use of tax rates as incentive in the competition for foreign factors and its importance in the decision-making process of taxpayers.

\subsection{Improves Efficiency of the Tax System}

The efficiency of a tax system is both economic and administrative. The attainment of the former is a function of whether the taxes therein leads to welfare loss above and beyond the tax revenues collected, or creates a substitutionary effect (i.e., causes economic actors to substitute taxed goods/services with untaxed or less taxed variants) or actuates economic actors into making decisions or taking actions geared towards tax burden minimizing. If the foregoing is the case, the tax system is inefficient. Thus, the avoidance and evasion strategies employed by economic actors as well as the cost of compliance are products of the efficiency or otherwise of the tax system. Compliance cost is used here to refer to the cost incurred by both the taxpayer and relevant tax authority (RTA) in the course of complying with the dictates of the tax system..$^{45}$ On the part of taxpayer, it includes the time and money spent in record keeping, computation, reporting, planning, etc. On the part of RTAs, it includes the time and money spent in assessment, audit, investigation and litigation relating to

45 For an estimate of the US compliance cost, see Arthur Laffer et al, “The Economic Burden Caused by Tax Code Complexity” (2011) <www.laffercenter.com/wpcontent/uploads/2011/06/2011-Laffer-TaxCodeComplexity.pdf $>$ accessed 3 July 2015. For statistic of cost of compliance in relation to GDP for Costa Rica and Uruguay, see UN, 'Measuring Tax Transaction Costs in Small and Medium Enterprises' (UN 2014) 101 and 189 <www.un.org/esa/ffd/documents/ TTC_Eng.pdf> accessed 6 November 2015. 
tax administration, etc.

In the realm of tax policy formulation, information pertaining to the efficiency of the tax system is necessary for international comparisons. For Nigeria, tax harmonization with trading partners or countries of the first world would improve the Nigerian tax system. This because the harmonization would provide Nigeria with a model to copy or adapt and benchmark against which its tax system can be appraised. The consequences of this includes reduction of welfare loss arising from the avoidance and evasion strategies employed by economic actors as well as the cost of tax administration and improved efficiency. The improved efficiency of the system is a positive indicator that is bound to favourably impact on Nigeria's business climate, ${ }^{46}$ economic growth and development.

\section{COST OF TAX HARMONIZATION}

Tax harmonization is not without downsides. These constitute costs for Nigeria and they include: ${ }^{47}$

\subsection{Loss of Sovereignty}

If Nigeria's efforts (and those of the supranational groupings it belongs to) are to be successful, of necessity, there has to be some ceding of fiscal sovereignty and jurisdiction over issues pertaining to the forums' fiscal architecture to the supranational entity. This is usually the case, as the document evidencing subscription to the grouping's objectives is deemed superior to the municipal legislation of the contracting parties. ${ }^{48}$ The International Court of Justice (ICJ) in its advisory opinion in the United

46 Nigeria currently ranks the lowest with reference to the time (hours per year) spent in the payment of tax in the ECOWAS region. See World Bank, Doing Business 2016: Measuring Regulatory Quality and Efficiency (13th ed, Washington, DC 2015), 65-68 <http://www.doingbusiness.org/reports/ /media/ GIAWB/Doing\%20Business/Documents/Profiles/Regional/DB2016/DB16Economic-Community-West-African-States.pdf $>$ accessed 6 November 2015.

47 It should be noted that the choice of those discussed hereunder was made pursuant to the response to interviews and discussion with tax policy officers in FIRS from between August-October 2013.

48 See Articles 26 and 27 of the Convention on the Law of Treaties 1969, 8 ILM 679, 690 (1969).

491988 ICJ 12 (Advisory Opinion of Apr. 26), reprinted in 27 ILM 808 (May 1988). 
Nations Headquarters Agreement case has reaffirmed this position. ${ }^{49}$ This issue is important because of the relationship between a state's fiscal architecture, its international trade capability and its right to determine its tax policy. These are part of the constituents of the sovereign right of any state. With reference to the aforementioned relationship, it is a fact that tariffs on local products and industries will impact on their ability to compete against imports. And when imports with relatively lower production cost emanates from protectionist jurisdictions, the competition ends in favour of the imports.

Also, with the standardization achieved via implementation of the ECOWAS CET, Nigeria would effectively cede the sovereignty of determining its import rates to other ECOWAS member states. This would be the case, if Nigeria implements the recommendation of the ECOWAS VAT Protocol which is to the effect that VAT within the region is to be charged at a rate that is between 10 and 20 per cent. However, with DTAs, there is less ceding, as Nigeria still has the opportunity of determining the extent to which it accepts or adopts international consensus on income taxation and the degree of bilateral tax harmonization.

A prevalent opinion in literature on the subject of sovereignty within the broad framework of tax harmonization is that there is need for a supranational tax entity whose focus is global. ${ }^{50}$ This thought is perceived to be a fall out of the activities and posturing of the OECD. ${ }^{51}$ According to proponents, the international tax organization should have the capacity

50 See Vito Tanzi, “Is there a Need for a World Tax Organisation?” in Assaf Ranzin and Effraim Sadka (eds), The Economics of Globalisation. Policy Perspectives from Public Economics, (CUP 1999) 173-186. David Spencer "Centrifugal vs. Centripetal Forces (Part 1)” (2010) Vol. 21(4) International Taxation, 38. See also, Vito Tanzi, “Building Fiscal Capacity through Greater Cooperation” $<w w w$. imf.org/external/pubs/ft/fandd/2001/03/tanzi.htm> accessed 23 August 2013.

51 Spencer (n 51) 42; Daniel Mitchell and Brian Garst, "The Unfortunate Genesis of an International Organisation" (2011) <http://freedomandprosperity.org/files/ OECD/OffshoreInv-OECD.pdf> accessed 23 December 2013. See Reuven S. Avi-Yonah, International Tax as International Laws: An Analysis of the International Tax Regime (CUP 2007) 78 and 183, where the author seems to suggest this when he stated that a coordinated withholding tax imposed and administered by OECD members is a better solution compared to a treaty network to combat tax competition for passive investment. For a sample of opinion of other writers on this subject, see also Allison Christians, "Sovereignty, Taxation and Social Contract” (2008), Vol. 18 Minnesota Journal of International Law $<$ http://ssrn.com/abstract=1259975> accessed 24 August 2013. 
to provide high-level tax advice to countries that request and need it as well as provide guidance to and surveillance of tax policy developments and actions that have cross-country implications. ${ }^{52}$

The issue with this proposal is that it is contrary to the canons of the sovereignty of states to which is attached the right of the state to use tax independently or in conjunction with other fiscal means to generate revenue for its use and the provision of public goods. ${ }^{53}$ Furthermore, subscription to international tax treaties, both bilateral and multilateral, generally obligates signatories to act as proxy tax administrators for treaty partner(s) within their jurisdiction. ${ }^{54}$ Stretching this assertion further, it means that states are obligated to use all their instruments and agencies to aid their treaty partner(s) in the enforcement of the latter's taxes within their territory. Associated with this obligation is an intrinsic cost to be borne by treaty partners notwithstanding the rule that the financial cost of revenue claims is charged to the debtor or the requesting states where the cost cannot be recovered from the debtor..$^{55}$ This intrinsic cost stems from the reallocation of the resources of the requested state from their primary assignment of tax administration to the provision of assistance to the requesting state pursuant to its treaty obligation. Furthermore, this development is contrary to the revenue rule ${ }^{56}$ which in its modern form allows courts to decline entertaining suits or enforcing foreign tax judgments or foreign revenue laws. ${ }^{57}$

Related to the issue of sovereignty is the obligation imposed on treaty

52 Tanzi (n 51). See also Jennifer E Farrell, The Interface of International Trade Law and Taxation: Defining the Role of the WTO (IBFD 2013) $236 \mathrm{ff}$.

53 For a plethora of literature which supports this position, see Christians (n 52), 6 (footnote 9).

54 This assertion finds support in international law; whether customary principles like pact sunt servanda or hard law like the Vienna Convention on the Law of Treaties. See Thuronyi (n 21), 118. Also, article 27 of the UN and OECD Models imposes this duty on treaty partners in relation to each other.

55 This rule and/or practise is subsumed in article 27, UN and OECD Models.

56 See Attorney General v. Lutwydge (1729) 145 Eng. Rep. 674 (Ex. Div.); the decision in Holman v. Johnson (1775) 1 Cowp. 341(per Lord Mansfield).

57 Brenda Mallinak, 'The Revenue Rule: A Common Law Doctrine for the TwentyFirst Century' (2006) Vol 16 Duke Journal of Contemporary and International Law, 79-124. In the light of today's reality, the rule is considered of high nuisance value as it can aid in international tax planning, tax evasion and is capable of negatively affecting the tax moral and burden in the state seeking to have its revenue law enforced in the foreign forum. See Mallinak (above), 115-124 for arguments for and against abandoning the revenue rule. 
partners to facilitate effective exchange of information and assistance between them by various instruments of harmonization. ${ }^{5}$ By virtue of these provisions, treaty partners allow into their jurisdiction, the presence of officials of their partner(s) who so request(s), to interview individuals and examine taxpayer records, whether or not there is mutuality of interest.

\subsection{Tax Base Erosion and Revenue Shifting ${ }^{59}$}

Harmonization has the capacity to bring about tax base erosion and profit shifting. For example, subscription to the ECOWAS CET system brings about loss of fiscal space for its subscribers. With regard to Nigeria, pursuant to the ECOWAS CET regime, industrial machinery and equipment, electricity generating sets which used to attract import duty of 15 per cent is now duty free, while finished goods mineral water, chocolate which used to attract import duty of 150 per cent and 100 per cent, respectively, now attract 20 per cent import duty. ${ }^{60}$ Consequentially, the tariff bands under the ECOWAS CET would lead to tariff contraction, tax base erosion and revenue shift.

DTAs also have similar consequences as they effectively shift tax revenue from investment income (passive income) in source state to resident state. In a tax treaty relationship between Nigeria and a developed country, Nigeria would be disadvantaged as some (if not all) income from

58 For DTAs, such provisions are adapted from article 26 of the UN and OECD Models. Another example is article 5, ATAF Agreement on Mutual Assistance in Tax Matters.

59 Tax base erosion and revenue shifting should not be perceived in the same light as base erosion and profit shifting (BEPS). The former relates to a contraction of the tax base and/or a reduction in the applicable tax rate as a result of the state's subscription to bilateral/multilateral instruments like DTAs which consequentially leads to movement of revenue outside the border of the subscribing state. This is different from BEPS which amounts to the extraction of pre-tax profits from high tax jurisdictions to low tax jurisdictions with the use of tax deductible expenses (e.g. interest, management fees, royalties, etc.) or acceptable transfer pricing or acceptable business structuring within a multinational group.

60 For an overview and comparative analysis of the old and new rate, see KPMG, "Implementation of the ECOWAS Common External Tariff and Destination Inspection Scheme in Nigeria" (July 2006) <www.kpmg.com/NG/en/ Issues AndInsights/ArticlesPublications/Documents/Newsletter\% 20 on $\% 20$ ECOWAS\%20Common \% 20External\%20Tariff-July\%202006.pdf> accessed 24 July 2013. 
any investment inflow from the developed country would move in the opposite direction. This is because DTAs characteristically allocate taxing rights $^{61}$ and provide relief in situations of double taxation. Furthermore, the provisions of articles 5 (4)-(6) of both the UN and OECD Models create opportunity for tax base erosion and revenue shifting. ${ }^{62}$ This is because it also creates exceptions to the permanent establishment (PE) rule used to determine when an enterprise has sufficient connection with a country to subject it to tax on its income attributable to the PE. ${ }^{63}$ In the circumstances, to avoid the burden of tax associated with a PE - and effectively erode the tax base and shift revenue from the source country - most TNCs create dependent agents with absolutely no right to conclude contracts involving their core business or having any economic impact on the core business of the TNC.

\subsection{Distortion of Neutrality of Tax System}

A tax system is neutral where taxpayers' allocative decisions are a product of market forces and not the taxes therein. A neutral tax is deemed efficient because it does not give rise to welfare loss or economic burden. In the realm of international taxation, neutrality is subsumed in the theory of capital export neutrality (CEN) and capital import neutrality (CIN). CEN and CIN have as their core the elimination of variance in tax systems so as to deny taxpayers the ability of reducing their tax burden by shifting their economic activities to states with more favourable tax systems. CEN is thus achieved when the outflow of capital from a state are not actuated by tax consideration, while CIN involves subjecting investment to similar treatment regardless of their origin.

Tax harmonization in its current form is erasing variance in the tax system of states and unwittingly creating them across regions as well as creating supranational tax jurisdictions in the course of standardization of tax systems. In the light of this, tax neutrality is distorted as economic actors are given the capacity to arrange their affairs in any way that best makes use of the variances which standardization introduces. For example, the DTA between Nigeria and China achieves CEN between them. But

61 See Articles 7, 10, 11, 12 and 21 of the UN and OECD Models. See similar provisions in articles 7, 10, 11, 12 and 22 of Nigeria-China DTA.

62 See section 5(4)-(6) of Nigeria-China DTA for similar provisions.

63 Brian J. Arnold and Michael J. McIntyre, International Tax Primer (2nd ed, Wolters Kluwer 2002) 166. 
its existence could lead to treaty shopping by economic actors not connected to the treaty partners if it provides them with an advantage. Therefore, the instrument of tax harmonization becomes a tool with which the neutrality of the Nigerian tax system and the behaviour of economic actors in relation to it are distorted.

\subsection{Abuse}

This is possible where there is a cross-border transaction within the jurisdiction of parties to a DTA. In such situation, it arises: (a) where a DTA is improperly used as a basis for tax avoidance, and/or (b) where the existence of DTA prevents the effective operation of municipal antiavoidance rules. The existence of a DTA between states ordinarily creates advantages for residents (and sometimes national/citizens) of contracting states. This advantage is often exploited (or abused) by TNCs that lack the requisite status and for who the treaty benefit was not intended as a means of tax avoidance. The prominent means of achieving this is usually with the use of a conduit entity resident in one of the contracting state.

A second form of abuse manifests where a taxpayer deliberately arranges its affairs in a manner that allows it benefit from the existence of a treaty provision which countervails municipal anti-avoidance provisions. This scenario is possible because, as has been stated (and it is trite), the provisions of treaties supersede the provisions of municipal legislation.

\subsection{Equity Concerns}

Tax harmonization brings about standardization, elimination of variances and differences in tax systems. This is oftentimes achieved without the setting up of structures and processes geared towards addressing the equity issues which the harmonization births in tax systems. This development has the capacity of jeopardizing inter-state tax equity. For example, in a situation where Nigeria pursues tax harmonization (via a DTA for example) with a developed country, there are bound to be equity issues as the taxpayers in the both states would receive equivalent treatment instead of the different treatment which their individual circumstances and peculiarities would ordinarily necessitate.

The intra-state equity is also not spared. The social contract, which is the basis of the existence of the state, loses it prominence where Nigeria enters into harmonizing arrangements and agreements without considering the interest of its citizens. The subscription to the ECOWAS CET without prior consideration of the impact on the economy is an 
example of this situation. The primary effect of this is loss of revenue to Nigeria as a result of reduction of rates to 35 per cent from a high of 150 per cent, insufficient protection of domestic enterprise and the 100 per cent increase of the duty on raw materials from 2.5 per cent to 5 per cent. $^{64}$

\section{PRACTICAL CHALLENGES TO TAX HARMONIZATION}

There exist issues which are relevant as they impact on the attainment of the objective(s) behind the adoption of this policy. Though not all come within the ambit of tax policy, they bring about challenges, which Nigeria has experienced (and would experience) in the course of harmonization of its tax system with that of other economies. Amongst them is the issue of definition. A practical example is the definition of the land mass referred to as Nigeria. Nigeria is as defined by sections 2 and 3 of the Constitution of the Federal Republic of Nigeria 1999 (as amended) (CFRN). Pursuant to the provisions of sections 44(3), 315(5), Part 1 of the First Schedule of the CFRN, Section 1 of the Land Use Act ${ }^{65}$ and section 1(1) of the Territorial Waters Act, ${ }^{66}$ it extends from the seabed and subsoil beginning from the low water mark from which the territorial waters of Nigeria are measured continuing seawards to a limit not exceeding 12 nautical miles. Any definition outside the foregoing is unconstitutional.

Another relates to the application of the destination principle in VAT administration in Nigeria. The destination and origin principles guide the application of VAT. The former has the effect of vesting capacity to charge VAT on the country where consumption takes place, while the latter vests capacity on the country where the transaction originates. ${ }^{67}$ Pursuant to the First Schedule of the VAT Act, Nigeria operates destination value added tax system (as all exported goods and services are VAT exempt) and has what is referred to as a territorial reach VAT. ${ }^{68}$

64 See KPMG (n 61). See also “The ECOWAS Common External Tariff (CET) and Regional Integration” (December 2012) Vol. 2 (2) ECOWAS Vanguard 1-8.

65 Cap L5 Laws of the Federation of Nigeria.

66 Cap T5 Laws of the Federation of Nigeria.

67 For an exposé on both principles, see Liam Ebril, et al, The Modern VAT, (IMF 2001), 176; Rebecca Millar, 'The Jurisdictional Reach of VAT' in Richard Krever (ed), VAT in Africa (PULP 2008) 175-214.

68 Alan Schenk and Oliver Oldman, Value Added Tax: A Comparative Approach: A Comparative Approach (CUP 2007) 188. 
The associated challenges arise when goods are supplied to a Nigerian entity located outside the territory of Nigeria or the supply relates to a business-to-consumer transaction involving a service that is not easily identifiable (e.g., electronic service) to a unregistered entity. ${ }^{69}$ In relation to the former, by operation of law the entity's consumption becomes VAT exempt by virtue of its location. The latter throws up challenges, which tax policy formulation, would have to contend with.

The issue of variance or mismatch of the taxpayers' ability to pay is also a challenge to the success of any harmonization policy. Where Nigeria pursues income tax harmonization with a state possessing taxpayers with higher ability to pay, the harmonization would catalyse a substitution effect. The taxpayers in reaction would work less. It also has the propensity of leading to labour mobility or migration to more favourable tax climes (and possible brain drain), etc.

\section{CONCLUSION}

The arguments above, though stylized, indicate that the option of tax harmonization as a route to attaining the integration of Nigeria with other economies has its costs and benefits. What has not been stated is how the adoption and implementation of this policy would impact on the development of Nigeria. Tax harmonization has the potential of ensuring equitable and fair taxation as well as the provision of sustainable revenue for the financing of public expenditure. Therefore, the relationship is that tax harmonization would provide sustainable revenue that can be put to use for the sustainable development of the state. The revenue is sustainable because it is derived per time from current tax bases without depriving future generations the capacity of contributing to the development of their milieu through their tax bases or contribution.

Albeit the foregoing, there are a few extra considerations that should pre-occupy tax policy formulators. It is of importance that the purpose of the harmonization should be predetermined before the commencement of the process. For example, it should be clear whether it is for the purpose of creating linkages to facilitate economic relationships; or for the purpose of signalling to the world that the state is a global player or courting accolades; or whether the purpose is for increasing revenue inflow. It is

69 Unregistered entity is used here to refer to an entity that is not obligated pursuant to section 8 of the VAT Act to register for VAT purposes. 
sequel to a decision on the foregoing that further decisions on the issue of the direction of the harmonization, who to harmonize with and the degree of the harmonization can then be taken. This would assist policy makers in balancing the down side (cost) of harmonization against the objective(s) to be achieved.

Tax policy is not insular and unconnected to other policies of the state. It is influenced by the foreign policy and development plan of the state. This means that for the benefits of harmonization to be fully realized, research and empirical information which would provide: (a) an understanding of the contemporary context; and (b) guide the formulation (and update) of a development plan of the state is needed. This would facilitate the understanding of the socio-economic cum political as well as situational dynamics of the state per time and a compass for determining the path to tread with regards to harmonization. Interviewees at FIRS surmised that decisions with regards to the direction/level of harmonization to pursue in Nigeria was reached without research and empirical information. To further substantiate the foregoing, one interviewee stated that if either were made use of, Nigeria ought to have negotiated and entered into DTAs with more African states or ECOWAS in view of the fact that more Nigerian business trade in these regions compared to the few who trade with the generality of its current DTA partners.

Closely related to the foregoing is the need to avoid politically motivated harmonization. It has been stated that Nigeria's adoption of the ECOWAS CET was driven by the politics of regional integration. ${ }^{70}$ The subsequent request for inclusion of the fifth band is support for the foregoing assertion. Consequently, if tax harmonization is to be worth anything to Nigeria, the degree and direction of harmonization should be based on the priority of its importance to the tax system, not on political convenience. Therefore, the decision as per the foregoing should be that which would avoid harmonization with no economic and developmental benefit for Nigeria.

70 Kehinde Ajayi and Philip Osafo-Kwaako, "Research and Trade Policy Formulation: The Case of Nigeria's Adoption of the ECOWAS Common External Tariff” (July 2007) Working Paper No. 78, 9 <www.inter-reseaux.org/ IMG/pdf_The_case_of_Nigeria_s_adoption_of_the_ECOWAS_CET.pdf $>$ accessed 28 September 2013. 
As highlighted before now, tax harmonization opens up the state to interference, tax base erosion and revenue shifting. In the light of these, there is the need for counter strategies where harmonization is favoured. To this end, tax administrators and policy formulators must mobilize fresh resources and imaginative solutions. With reference to Nigeria's tax base, not only should it be protected, policies that can expand it should be put in place. Thus, the following are proposed. The top marginal rate of personal income tax, which is currently 24 per cent ${ }^{71}$ should be reduced to put it at par with the lower marginal rate of company income tax which is currently 20 per cent for small companies. ${ }^{72}$ This would make tax arbitrage, base erosion, revenue shifting and other avoidance schemes less attractive to individuals as well as ensure that revenue needed to finance development is retained within the jurisdiction.

It is further suggested that TIEAs and Multilateral Conventions should be negotiated and signed where the purpose of harmonization is exchange of information for tax purposes. This is preferred as: (a) they are less intrusive; (b) they do not limit the fiscal space of contracting parties; (c) they do not impose other treaty obligations in the manner of DTAs; and with specific reference to Nigeria, they are cheaper in terms of the cost associated with their coming into being or its assent to the DTAs or their implementation within Nigeria. ${ }^{73}$

71 See section 34, Personal Income Tax (Amendment) Act 2011 which amends the Sixth Schedule of the PITA (the principal Act).

72 See section 40(6), CITA.

73 Pursuant to the provisions of section 12 CFRN, implementation of treaties/ conventions in Nigeria is by transformation. That is, before any obligation arising from therefrom becomes binding and enforceable in Nigeria, the latter must specifically be enacted by the National Assembly as municipal legislation. See Abacha v Fawebinmi (2001) 4 SCNJ 400; cf Medical Health Workers Union of Nigeria $v$ Minister of Labour and Productivity [2004)] NWLR (Pt. 953) 1, 23-24 where the Court of Appeal, relying on the decision in Abacha v Fawebinmi (supra) held that $\mathrm{t}$ signed International Labour Organisation Convention was inapplicable in Nigeria because it had not been enacted into law by the National Assembly. This requirement creates extra cost that becomes associated with the tax system of the state. In the case of Nigeria, the cost stems from the time and human effort that would go into the enactment of the DTA into law by the National Assembly. 
Appendix 1: Summary of Nigeria's DTA standing

\begin{tabular}{|c|c|c|c|c|c|}
\hline$S / N$ & Countries & DTA Type & Date of Signing & $\begin{array}{l}\text { Date of } \\
\text { Entry into } \\
\text { Force }\end{array}$ & $\begin{array}{l}\text { Effective } \\
\text { Date }\end{array}$ \\
\hline 1 & Belgium & Comprehensive & $\begin{array}{l}20 \text { November } \\
1989\end{array}$ & $\begin{array}{l}\text { 1 January, } \\
1990\end{array}$ & $\begin{array}{l}\text { 1 January } \\
1991\end{array}$ \\
\hline 2 & Canada & Comprehensive & 4 August 1992 & $\begin{array}{l}16 \\
\text { November, } \\
1999\end{array}$ & $\begin{array}{l}1 \text { January } \\
2000\end{array}$ \\
\hline 3 & China & Comprehensive & 15 April 2005 & $\begin{array}{l}21 \mathrm{March} \\
2009\end{array}$ & $\begin{array}{l}1 \text { January } \\
2010\end{array}$ \\
\hline 4 & $\begin{array}{l}\text { Czech } \\
\text { Republic }\end{array}$ & Comprehensive & 31 August 1989 & $\begin{array}{l}2 \text { December } \\
1999\end{array}$ & $\begin{array}{l}1 \text { January } \\
2000\end{array}$ \\
\hline 5 & France & Comprehensive & $\begin{array}{l}27 \text { February } \\
1990\end{array}$ & 2 May 1991 & $\begin{array}{l}1 \text { January } \\
1992\end{array}$ \\
\hline 6 & Italy & $\begin{array}{l}\text { Air \& Shipping } \\
\text { Agreement Only }\end{array}$ & $\begin{array}{l}22 \text { February } \\
1976\end{array}$ & 1977 & $\begin{array}{l}1 \text { January } \\
1978\end{array}$ \\
\hline 7 & Mauritius & Comprehensive & 10 August 2012 & $\begin{array}{l}\text { Not yet in } \\
\text { force }\end{array}$ & - \\
\hline 8 & Netherlands & Comprehensive & $\begin{array}{l}11 \text { December } \\
1991\end{array}$ & $\begin{array}{l}9 \text { December } \\
1992\end{array}$ & $\begin{array}{l}1 \text { January } \\
1993\end{array}$ \\
\hline 9 & Pakistan & Comprehensive & $\begin{array}{l}10 \text { October } \\
1989\end{array}$ & $\begin{array}{l}7 \text { March, } \\
1990\end{array}$ & $\begin{array}{l}\text { 1 January } \\
1991\end{array}$ \\
\hline 10 & Philippines & Comprehensive & $\begin{array}{l}30 \text { September } \\
1997\end{array}$ & $\begin{array}{l}\text { Not yet in } \\
\text { force }\end{array}$ & - \\
\hline 11 & Poland & Comprehensive & $\begin{array}{l}12 \text { February } \\
1999\end{array}$ & $\begin{array}{l}\text { Not yet in } \\
\text { force }\end{array}$ & - \\
\hline 12 & $\begin{array}{l}\text { Republic of } \\
\text { Korea }\end{array}$ & Comprehensive & $\begin{array}{l}6 \text { November } \\
2006\end{array}$ & $\begin{array}{l}\text { Not yet in } \\
\text { force }\end{array}$ & - \\
\hline 13 & Romania & Comprehensive & 21 July 1992 & 18 April 1993 & $\begin{array}{l}\text { 1 January } \\
1994\end{array}$ \\
\hline 14 & Slovakia & Comprehensive & 31 August 1989 & $\begin{array}{l}2 \text { December } \\
1990\end{array}$ & $\begin{array}{l}1 \text { January } \\
2000\end{array}$ \\
\hline 15 & $\begin{array}{l}\text { South } \\
\text { Africa }\end{array}$ & Comprehensive & 29 April 2000 & $\begin{array}{l}1 \text { January } \\
2009\end{array}$ & $\begin{array}{l}1 \text { January } \\
2009\end{array}$ \\
\hline 16 & Spain & Comprehensive & 23 June 2009 & $\begin{array}{l}\text { Not yet in } \\
\text { force }\end{array}$ & - \\
\hline 17 & Sweden & Comprehensive & $\begin{array}{l}18 \text { November } \\
2004\end{array}$ & $\begin{array}{l}\text { Not yet in } \\
\text { force }\end{array}$ & - \\
\hline 18 & $\begin{array}{l}\text { United } \\
\text { Kingdom }\end{array}$ & Comprehensive & 9 June 1987 & $\begin{array}{l}1 \text { January } \\
1988\end{array}$ & $\begin{array}{l}1 \text { January } \\
1989\end{array}$ \\
\hline
\end{tabular}

Source: Exchange of Information Portal (2013) and FIRS, Tax Treaties (2013)

74 This treaty and that with Philippines, Poland, Republic of Korea, Spain and Sweden do not have effective dates because they are yet to enter into force. A tax treaty usually enters into force 30 days after the final/last notification between treaty partners that constitutional or legal procedures required to make the treaty enforceable in each contracting state have been completed. The effective date is usually the first date of the next assessment year. In the case of aforementioned treaties, the final notification is yet to be received.

75 The Exchange of Tax Information Portal is an initiative of the OECD Global Forum on Transparency and Exchange of Information for Tax Purposes. For more information, visit <http://eoi-tax.org/> accessed 25 October, 2013.

76 For more information, visit $<w w w . f i r s . g o v . n g / T a x-M a n a g e m e n t / P a g e s / T a x-$ Treaties.aspx $>$ accessed 12 October, 2013. 


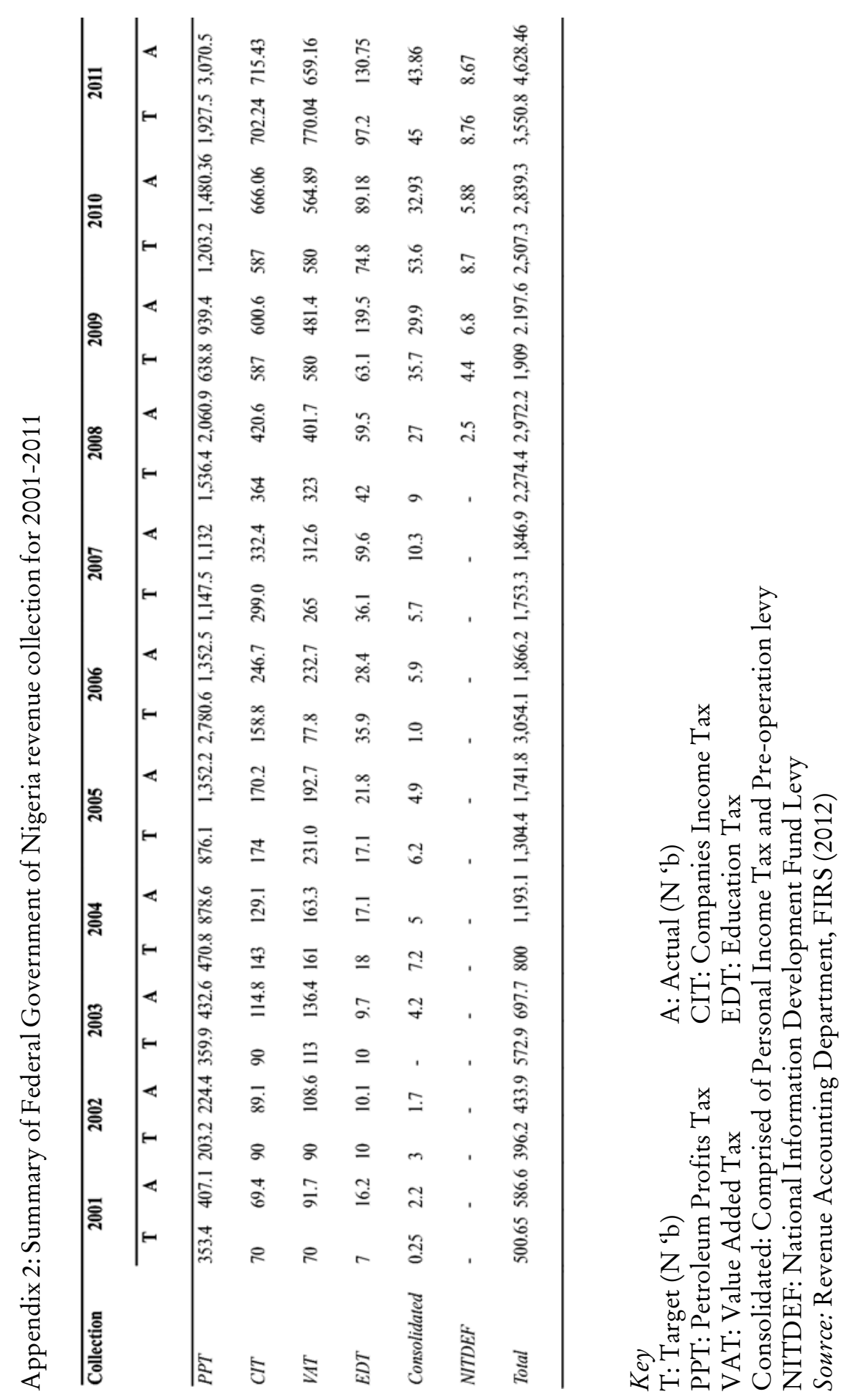




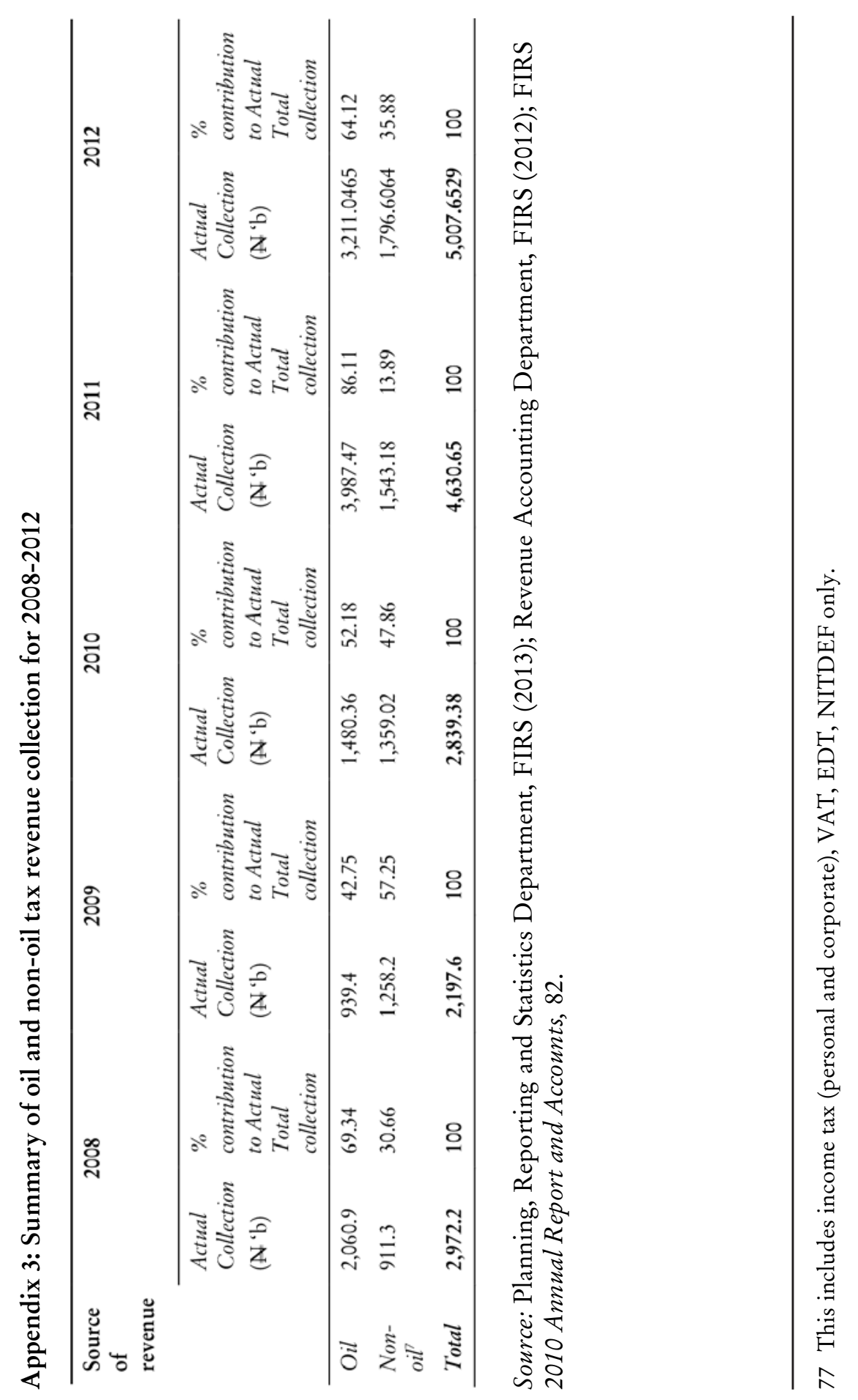

